\title{
Comments on the treatment of the Poaceae in the Prodromus einer Flora von Südwestafrika (1970)
}

\section{B. DE WINTER* \& P. VORSTER*}

\section{INTRODUCTION}

The latest available revision of the Poaceae (Gramineae) of South West Africa appeared in Merxmüller's "Prodromus" (1970) under the authorship of E. Launert. During the compilation of the Master Index of South African Grasses, being undertaken by the National Herbarium, Pretoria, a number of species not recorded in the Prodromus came to light. Some of these have, so far, been found only in the Caprivi Strip, an area specifically excluded from the Prodromus since it is covered by the Flora Zambesiaca. For the purposes of the preparation of the Flora of Southern Africa it is useful, however, to bring the record up to date.

In a number of instances the species delimitation adopted in the Prodromus is at variance with our views. Since some of these concern species with a mainly South African distribution, it was regarded as necessary to elaborate on these differences even though complete revisions of the groups concerned could at present not be undertaken. Unnecessary name changing and confusion will thus be avoided.

\section{COMMENTS ON SPECIES DELIMITATION, NOMEN-} CLATURE AND IDENTIFICATIONS

Chloris radiata (L.) Swartz. S.W.A.-2117 (Waterberg): Waterberg (-?), Giess, Volk \& Bleissner 6615. Launert (p. 48) cites this number as $C$. virgata Swartz.

Echinochloa frumentacea (Roxb.) Link. S.W.A.1821 (Andara): Kaké Camp between Andara and Bagani (-BA), De Winter \& Wiss 4373. (Cited by Launert p. 71 as E. crusgalli (L.) Beauv. This material matches the type of $E$. frumentacea which we regard as a distinct species.

Eragrostis trichophora Coss. \& Dur. De Winter 2378 is E. trichophora, not E. lehmanniana Nees as quoted by Launert (p. 108). Note the whorled lower branches of the inflorescence and the grey membranous glumes. S.W.A.-2217 (Windhoek): Neudamm Experimental Farm (-AD), De Winter 2378.

Paspalum paspalodes (Michx.) Scribn. Launert (p. 146) sinks $P$. vaginatum $\mathrm{Swartz}$ as a synonym under $P$. distichum L. Clayton in Fl. W. Trop. Afr. ed 2,3: 446 (1972) proposes to reject $P$. distichum as a nomen confusum, as the name has constantly been misapplied. We concur with his proposal, and if accepted, this means that the species erroneously regarded as $P$. distichum by most authors, needs a new name. According to Clayton (personal communication) the earliest name available is $P$. paspalodes (Michx.) Scribn. S.W.A.-2417 (Mariental): Hardapdamm, GIB 110 (-DB), Giess, Volk \& Bleissner 5598.

Paspalum vaginatum Swartz. This species is synonymous with $P$. distichum $L$. as was recognised by Launert (p. 146). We regard $P$. distichum as a nomen confusum (see above). The earliest alternative name available for this entity is $P$. vaginatum Swartz. S.W.A.-2214 (Swakopmund): Swakopmund (-DA), Research Station Gobabeb 00102; Van Vuuren 987.

* Botanical Research Institute, Private Bag X101, Pretoria.
Setaria tenuiseta De Wit. S.W.A.-1718 (Kuringkuru): Makambu Camp 32,8 km west of Kuringkuru on the way to Katwitwi (-BC), De Winter \& Marais 5023. This specimen is cited, incorrectly in our opinion, as Setaria finita Launert (Launert, 1.c. p. 173).

Setaria ustilata De Wit. S.W.A-1821 (Andara): between Bagani Camp and Mahango (-BA), De Winter \& Wiss 4403. 1917 (Tsumeb): ca. $16 \mathrm{~km}$ southeast of Tsumeb (-BD), Basson 42.2115 (Karibib): Ohere-Ost (-BA), Merxmüller \& Giess 1594. Merxmüller \& Giess 1594 is cited by Launert (1.c. p. 173) as S. pallide-fusca (Schumach.) Stapf \& C. E. Hubb. We consider $S$. ustilata to be distinct from $S$. pallide-fusca. The specimens cited above match the type of $S$. ustilata in PRE. Ecologically they occupy a habitat distinct from that of $S$. pallide-fusca. $S$. pallide-fusca is a weed of agriculture and, where the rainfall is low, prefers moist habitats. In areas of higher rainfall it is common in disturbed areas as a ruderal weed. $S$. ustilata, on the other hand, is confined to semidisturbed areas which are more arid, where it usually grows in shady places, particularly in the humus-rich soil under trees. Whereas it seems to grade into $S$. pallide-fusca in the tropics, and is apparently included in the latter in the Flora of Tropical Africa, it is sufficiently distinct in our area to be separated as a species. See Stapf in Fl. Trop. Afr. 9: 819 (1930). There may be an older name for this taxon, but, until this is established, there seems to be no alternative to using De Wit's name.

Sporobolus acinifolius Stapf, S. glaucus Mez, S salsus Mez and $\mathbf{S}$. tenellus (Spreng.) Kunth

No material which we would refer to $S$. tenellus sensu stricto was seen from South West Africa or Botswana, nor do we regard $S$. acinifolius as being synonymous with $S$. tenellus. $S$. acinifolius is, however, fairly widely distributed in all these territories. Although occasionally difficult to distinguish, these two species are in our opinion justifiably retained as distinct species by Chippindall in Grasses and Pastures of South Africa (1955).

The sinking of $S$. salsus and $S$. glaucus into synonymy under $S$. tenellus can also not be supported. However, S. salsus and S. glaucus, in our opinion, represent one species in spite of the difference in size of the spikelets. In habit the latter two agree closely, being distinctly tufted with fairly long leaves. By contrast, $S$. acinifolius has a branched rhizome producing short leaves, the basal parts being matforming. The spikelets are 1,4-1,6 mm long in $S$. acinifolius and $2,0-2,9 \mathrm{~mm}$ in $S$. salsus (syn. $S$. glaucus). The Southern African specimens were identified by us as shown below.

S. acinifolius Stapf. S.W.A.-1815 (Okahakana): Gemsbocklaagte, Etoshapfanne, Giess 2213. 1816 (Namutoni): Namutoni (-DD), Volk 2612; east of Namutoni (-DD), De Winter 2969. 2015 (Otjihorongo): district Outjo, Wittklipp (-AC) Volk 2873. 2115 (Karibib): Okaukuejo, bei Okandeka (-DA), 
Giess, Volk \& Bleissner 6108. 2217 (Windhoek): Neudamm Experimental Farm (-AD), De Winter 2375. 2517 (Gibeon): 2,2 km north of Asab (-BD), De Winter 3478. 2519 (Koës): near Koës (-CC), Acocks 15599. CAPE.-2624 (Vryburg): Vryburg (-DC), Rodger sub PRE 32349; Henrici 174. 2723 (Kuruman): Kuruman (-AD), Mogg 7635; Cardington (-BA), Esterhuysen 2215; $38 \mathrm{~km}$ east of Kuruman on the road to Vryburg (-BD), Codd 1294. 2822 (Glen Lyon): Lucas Dam (-BB), Wilman sub PRE 32350 2824 (Kimberley): Koopmansfontein (-AA), Brueckner 187; Barkly West (-DA), Acocks 155

S. salsus Mez (Syn.: S. glaucus Mez). S.W.A.1815 (Okahakana): E.N.P. Ondongab (-?), Du Toit \& Le Roux 456; 457; between Namutoni and Okakwea (-DC), Volk 2413. 2416 (Maltahöhe): 48 km north of Mariental (-BA), Basson 268. 2417 (Mariental): Farm Narib GIB 106 (-BA), Giess, Volk \& Bleissner 5624

The specimens De Winter \& Marais 4666 from 13 $\mathrm{km}$ east of Tamso Camp in Omuramba Khaudum and Le Roux 278 from Fischers Pan, Etosha National Park, are best placed under $S$. salsus for the present. More material is needed to determine whether they form a part of the variation of this species.

S. tenellus (Spreng.) Kunth. No material of this species, sensu stricto, is known to us from South West Africa. The following South African specimens are referred to $S$. tenellus by us: O.F.S. -2728 (Frankfort): Naauwpoort (-BC), Sim s.n. 2825 (Boshof): Boshof (-CA), Burtt Davy 12399; 21 km N.N.E. of Dealesville (-DB), Acocks 14012. 2924 (Hopetown): Luckhoff (-DB), Henrici 2156; Bergrivier, Fauresmith (-DD), Smith 5429. 2925 (Jagersfontein): Fauresmith (-CB), Smith \& Pole Evans sub PRE 8831; Verdoorn 896; Henrici 3069. 2926 (Bloemfontein): Bloemfontein distr. (-AA), Acocks 12511. CAPE.-2824 (Kimberley): Rooipoort (-CA), Leistner 1229. 3023 (Britstown): Omdraaisvlei (-AA), Bryant 1190; Britstown (-DA), Von Broembsen 81. 3025 (Colesberg): Knoffelfontein (-AA), Smith 5385; Vrede, Philippolis (-AD), Smith 4347A. 3026 (Aliwal North): Groenvlei (-AD), Henrici 3905; 3905 A; 3905B; 3905C; Smith 3889. 3122 (Loxton): $61 \mathrm{~km} \mathrm{S.E.} \mathrm{of} \mathrm{Loxton} \mathrm{(-DD),} \mathrm{A} \mathrm{cocks} 14377$. 3124 (Hanover): 24 km S.S.E. of Richmond (-AA), Acocks 15849; Hanover (-AB), Acocks 16350. 3322 (Beaufort West): Driefontein (-BC), Van der Merwe 2775. 3324 (Steytlerville): $34 \mathrm{~km}$ from Steytlerville on the road to Uitenhage (-DA), Story 2337

Sporobolus natalensis (Steud.) Dur. \& Schinz. Clayton in Fl. W. Trop. Afr. ed 2, 3: 410 (1972) points out that $S$. natalensis probably belongs in the synonymy of $S$. africanus (Poir.) Robyns \& Tournay or may be of hybrid origin. De Winter 3980 cited by Launert (p. 184) under $S$. natalensis is a fairly typical specimen of $S$. pyramidalis Beauv. S.W.A. -1718 (Kuring-Kuru): junction of Mpungu Omuramba and Okavango River between Tondoro and Lupala (-DD), De Winter 3980.

Sporobolus subtilis Kunth, S. conrathii Chiov. and S. welwitschii Rendle

We regard the first two species as distinct, not only from one another, but also from $S$. welwitschii Rendle, for the following reasons: $S$, subtilis has the rhachilla produced and, like $S$. welwitschii, has slender, oblique rhizomes terminating the culms (or clusters of culms) at the base. It favours wet places such as vleis. S. conrathii has no produced rhachilla and the habit is caespitose with a dense covering of fibrous old sheaths at the base (unlike $S$. welwitschii). No rhizomes have been noted. It prefers open grassland but is occasionally found in wetter places.
S. subtilis Kunth. TransvaAL. -2528 (Pretoria): Rayton (-DA), De Winter 276; Schweickerdt 1756 2630 (Carolina): Athole Pasture Research Station (-CA), Norval 69. NATAL.-2732 (Ubombo): Mpangazi Lake (-DA), Strey \& Huntley 5013. Not recorded from S.W.A.

S. conrathii Chiov. S.W.A.-1724 (Katima Mulilo): $3 \mathrm{~km}$ southwest of Katima Mulilo (-CB), De Winter 9189. 1820 (Tarikora): 24,9 km. S. of Kapupahedi on the track to Tamso (-DC), De Winter \& Marais 4639. TransvaAl. -2428 (Nylstroom): Sterkrivier Dam (-BC), Jacobsen 2614. 2528 (Pretoria): Premier Mine (-DA), Menzies 16; Rayton (-DA), Schweickerdt 1826. Grid reference unknown: Rustenburg distr., Crocodile River, Schlechter 3977; Frankenwald, $H B G$ 25042. O.F.S.-Grid reference unknown: Maccau Vlei, Brandmuller 36.

S. welwitschii Rendle (syn.: S. baumianus Pilg., $S$. macrothrix Pilg.). These three species are indistinguishable morphologically except by the length of the spikelets which are $0,8-1,0 \mathrm{~mm}$ long in $S$. baumianus, 1,2-1,3 mm in $S$. welwitschii and 1,9-2,1 $\mathrm{mm}$ in $S$. macrothrix. The bases of the type specimens of these three species agree in that the new shoots are enveloped in cataphylls. Long, fibrous, basal sheaths, typical of $S$. conrathii, are always absent. In habit as well as in the characteristics of the bases, the specimens cited below resemble $S$. subtilis Kunth, but the rhachilla is never produced

S.W.A.-1724 (Katima Mulilo): Katima Mulilo area (-AD), Killick \& Leistner 3110. 1820 (Tarikora) $13 \mathrm{~km}$ east of Tamso in Omuramba Khaudum (-DA), De Winter \& Marais 4681. De Winter \& Marais 4639 named $S$. welwitschii by Launert (p. 186) is $S$. conrathii Chiov.

\section{NEW RECORDS FOR THE AREA COVERED BY THE PRODROMUS}

Alloteropsis cimicina (L.) Stapf. S.W.A. -1720 (Sambio): 31,6 km west of Nyangana Mission on road to Rundu (-DC), De Winter \& Marais 4582. 1724 (Katima Mulilo): 4,8 km east of Katima Mulilo (-AD), De Winter 9141; ca. 11,2 km south of Katima Mulilo on the road to Ngoma (-CB), Killick \& Leistner 3027

Bromus diandrus Roth. S.W.A.-2416 (Maltahöhe): Buellsport (-AB), Strey 988. Introduced species, probably an escaped weed of cultivation.

Diplachne biflora Hack. ex Schinz. S.W.A.-1720 (Sambio): 3,8 km east of Masari Camp on road to Nyangana (-CC), De Winter \& Wiss 4086

Diplachne eleusine Nees. S.W.A.-1913 (Sesfontein): $4 \mathrm{~km}$ east of Sesfontein (-BA), De Winter \& Leistner 5584 .

Eragrostis habrantha Rendle. S.W.A.-1718 (Grootfontein): Grootfontein (-CA), Engler 6256. 2518 (Tses): Asis (-BC), Volk A. 39 in NH 30761.

Hyparrhenia dregeana (Nees) Stapf ex Stent. S.W.A.-1917 (Tsumeb): Auros, Hochtalboden (-DA), Volk 624

Monocymbium ceresiiforme (Nees) Stapf. S.W.A.1819 (Karakuwisa): Omuramba Omatako 66,9 km south of Rundu (-DA), De Winter \& Marais 5048 1920 (Tsumkwe): Gautscha Pan (-DC), Watt S.W.A. 2395.

Paspalidium cf. P. platyrrhachis C. E. Hubb. S.W.A.-1719 (Rundu): Rundu (-DD), Volk 1795 (This genus is in need of revision.)

Poa annua L. S.W.A.-2116 (Okahandja): Ondonganji, $24 \mathrm{~km}$ east of Omaruru (-AC), Maguire 2051 (Common, weedy, introduced species). 
Setaria cana De Wit. S.W.A.-2117 (Waterberg): Waterberg (-AC), Boss sub TRV 36343. This specimen is represented in PRE by the holotype only. It seems to be related to $S$. phragmitoides Stapf and may prove to be synonymous with this species.

\section{NEW RECORDS FOR THE CAPRIVI STRIP}

Dinebra retroflexa (Vahl) Panz. S.W.A.-1725 (Livingstone): Mpilila Island (-CC), Killick \& Leistner 3342; Mpilila Island (-CC), De Winter 9242.

Echinochloa frumentacea (Roxb.) Link. S.W.A.1724 (Katima Mulilo): 12,9 km west of Katima Mulilo (-DB), De Winter 9132.
Entolasia imbricata Stapf. S.W.A.-1723 (Singalamwe): Singalamwe (-CB), Killick \& Leistner 3240.

Leptochloa uniflora Hochst. ex A. Rich. S.W.A.1725 (Livingstone): Mpilila Island (-CC), Killick \& Leistner 3347.

Loudetiopsis glabrata (K. Schum.) Conert. S.W.A.1724 (Katima Mulilo): Katima Mulilo (-AD), Ellis 344; Kabe floodplains (-DA), Brown s.n.

Monocymbium ceresiiforme (Nees) Stapf. S.W.A.1724 (Katima Mulilo): ca. $80 \mathrm{~km}$ from Singalamwe on road to Katima Mulilo (-CA), Killick \& Leistner 3289.

Sporobolus stapfianus Gand. S.W.A.-1724 (Katima Mulilo): Ngoma area (-DC), Killick \& Leistner 3003. 